\title{
FRIENDLY INSECTICIDES TO CONSERVE BENEFICIAL INSECTS
}

\author{
Dunston P.Ambrose
}

Entomology Research Unit, St. Xavier's College (Autonomous), Palayankottai, Tamil Nadu 627002, India.

Email:dpambrose@vsnl.com,sxcent@md4.vsnl.net.in

\begin{abstract}
Many insecticides used in agroecosystems target insect pests along with beneficials or natural enemies. Insecticides should not only suppress the insect pest population, but also be safer to their natural enemies. Hence, it is imperative to screen the insecticides before incorporating them into the Insect Pest Management Programme. Such screening of insecticides will be successful and effective only when we understand the toxicological effects of insecticides we use, on insect pests as well as on their predators. The present paper reviews the impact of insecticides on beneficials with special reference to four non-target reduviid predators viz., Acanthaspis pedestris (Stål), Rhynocoris fuscipes (Fabricius), R. kumarii (Ambrose \& Livingstone) and $R$. marginatus (Fabricius) that prey on insect pests and are being exposed to insecticides used by farmers. Almost all the tested insecticides with reference to this review prolonged the postembryonic development; altered the sex ratio; reduced the size and the weight of life stages; and the fecundity and the longevity; caused low prey consumption, haphazard movement; loss of orientation and restlessness; altered their haemogram; accelerated mitosis as well as transformation of haemocytes; reduced carbohydrate and protein and increased lipid and water content; disintegrated alimentary canal, testis and ovary and reduced sperm count and distorted sperms.
\end{abstract}

\section{Key words}

Insecticides, impact, beneficial non-target insects

\section{Introduction}

Insecticides are not only the culprits of well known ecological backlashes: resurgence, resistance and replacement, environmental microbial degradation and so on, but also affect the non-target arthropods. Historically, biological impact of insecticides on arthropods have been evaluated primarily on mortality assessments. However, it is well known, that sublethal doses of insecticides can affect the physiology and behaviour of both target and non-target arthropods. It alters their ability to regulate the density of their hosts or prey. This ability in beneficials may be affected in two ways, (i) changes in the intrinsic rate of increase such as developmental rate, fecundity, longevity and sex ratio, and/or (ii) changes in the feeding behaviour, such as general mobility, host searching and oviposition (Croft, 1990).

Although the formulation, timing and placement of field application are directed as narrowly as possible at target pests, beneficials are often more susceptible to insecticides than phytophagous pests, because they are continuously exposed to the longer period of the degradation of insecticides. Under ideal conditions of ecological selectivity, the toxicant would affect only the pest and would have no effect on beneficials. In reality, however, selectivity is imperfect and some overlap of insecticide exposure on beneficials invariably occurs and the sublethal effects also follow. Beneficials are usually dependent on their phytophagous prey for their food and reproduction. Hence, their developmental characteristics have evolved to follow those of their prey with some lag time. For instance, when insecticides are applied to early generation of the pest, subsequently emerging beneficials are likely to encounter sublethal residues. Since natural enemies are more mobile they are more likely to come in contact with sublethal residues of insecticides. Hence, awareness of screening of insecticides, safer to biological control agents has been gaining momentum (Ambrose, 1999). Such screening is imperative to safeguard the beneficials from the hazardous effects of insecticides. This paper reviews the insecticidal damages caused on the postembryonic development, behaviour, predatory potential, haematology, biochemistry and histology of reduviids, potential biological control agents of insect pests.

\section{Review}

Toxicity

The impact of three commonly used insecticides viz., 
decamethrin, sumicidin and dimethoate against cotton and vegetable pests, to a non-target reduviid biocontrol agent $A$. pedestris nymphal instars was studied. Based on the 24, 48, 72 and $96 \mathrm{hr} \mathrm{LC}_{50}$ their order of toxicity was ranked as follows: dimethoate $>$ decamethrin $>$ sumicidin. All three insecticides affected the behaviour of insects. The $\mathrm{LC}_{50}$ value increased from first to fifth nymphal instar but it decreased from 24-hr to 96-hr exposure (Sahayaraj, 1991).

The relative toxicity of monocrotophos, and dimethoate in five concentrations, each concentration when evaluated at four different exposure periods to A. pedestris indicated that monocrotophos was more toxic than dimethoate. The field application level of dimethoate ( $300 \mathrm{ppm}$ ), had no toxic effect on the predator, whereas monocrotophos (field level $360 \mathrm{ppm}$ ) had little effect. The third nymphal instar was more resistant to monocrotophos than the adults due to their camouflaging behaviour (Ambrose \& George, 1995, 1996a, b, 1998). Cypermethrin was also found toxic to A.pedestris (Khan, 2000).

Toxicological impacts of four insecticides: monocrotophos, dimethoate, quinalphos and endosulfan on the postembryonic development, haematology, biochemistry and histology of three harpactorine reduviid predators viz., $R$. fuscipes, $R$. kumarii and R. marginatus were studied (George, 1996; George \& Ambrose, 1997, 1998a, b). All the five insecticides were found to be toxic even at $24 \mathrm{hrs}$ exposure. The relative toxicity of insecticides was rated as follows: methylparathion > monocrotophos > dimethoate $>$ quinalphos $>$ and endosulfan. Among the three harpactorines, $R$. marginatus was the most resistant while $R$. fuscipes was the least resistant (Table 1; Figure 1). Analysis of $\mathrm{LC}_{50}$ values revealed that third nymphal instars were more sensitive than the adults. $\mathrm{LC}_{50}$ values also supported the relative toxicity of the tested insecticides, by mortality observation. George and Ambrose (1996) reported that the higher morph of $R$. marginatus was more resistant than $R$. kumarii and $R$. fuscipes to monocrotophos and endosulfan.

Synthetic insecticides quinalphos, phosphamidon, dimethoate,

Table 1. $L C_{50}(\%)$ values of insecticides (actual concentration) on the three harpactorine reduviids at $96 \mathrm{hrs}(n=30)$

\begin{tabular}{llll}
\hline Insecticide & R. fuscipes & $\begin{array}{l}\text { Reduviid } \\
\text { R. kumarii }\end{array}$ & R. marginatus \\
\hline Monocrotophos & 0.022 & 0.047 & 0.048 \\
Dimethoate & 0.043 & 0.053 & 0.085 \\
Quinalphos & 0.045 & 0.061 & 0.082 \\
Endosulfan & 0.114 & 0.128 & 0.189 \\
\hline
\end{tabular}

Source: George, 1996; George \& Ambrose, 1997, 1998a, 1998b.

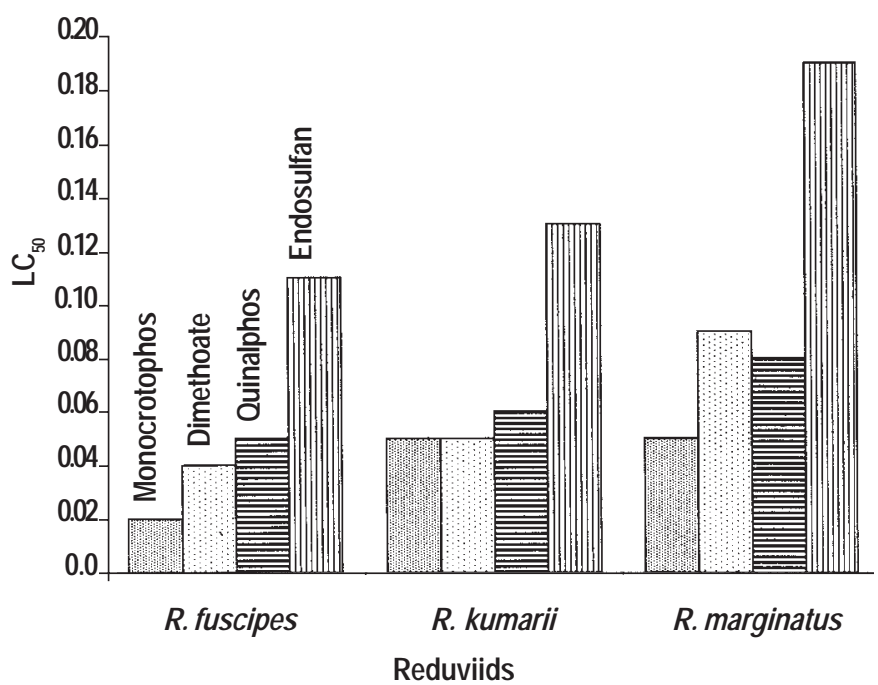

Figure 1. $L C_{50}$ of insecticide (actual concentration) on three harpactorine reduviids at 96 hours

methylodemeton, monocrotophos, chlorpyriphos and endosulfan and botanicals nimbecidine, niconeem, neemark and nicotene sulphate were toxic to eggs and nymphs of $R$. fuscipes. Among synthetic and botanical insecticides quinalphos and nimbecidine were found highly toxic and endosulfan and nicotine sulphate were the least toxic, respectively (Paul \& Srivastava, 1989; Ghelani et al., 2000).

\section{Postembryonic development}

Monocrotophos negatively prolonged the stadial period and shortened the longevity of $A$. pedestris. Except endosulfan all the other tested insecticides significantly prolonged the stadia and delayed the emergence of adults in Rhynocoris spp. (George, 1996; George \& Ambrose, 1998c, 1999c, e) (Table 2; Figure 2). Such insecticides influencing postembryonic development was observed in natural enemies belonging to Braconidae, Coccinellidae, Chrysopidae, Encrystidae, Ichneumonidae

Table 2. Impact of insecticides on the stadial period (days) of three harpactorine reduviids ( $n=4$ to $16 ; \pm S E$ )

\begin{tabular}{|c|c|c|c|}
\hline Insecticide & R. fuscipes & $\begin{array}{l}\text { Stadial period } \\
\text { R. kumarii }\end{array}$ & R. marginatus \\
\hline Control & $42.700 \pm 0.448$ & $81.667 \pm 1.210$ & $82.636 \pm 2.309$ \\
\hline Monocrotophos & $44.467 \pm 0.624$ & $94.600 \pm 1.195$ & $89.357 \pm 1.349$ \\
\hline Dimethoate & $44.769 \pm 0.496$ & $89.286 \pm 0.873$ & $85.833 \pm 1.566$ \\
\hline Quinalphos & $43.538 \pm 0.461$ & $93.333 \pm 0.980$ & $86.250 \pm 0.789$ \\
\hline Endosulfan & $40.077 \pm 0.684$ & $89.083 \pm 0.933$ & $76.333 \pm 1.096$ \\
\hline
\end{tabular}

Source: George, 1996; George \& Ambrose, 1998c, 1999c, 1999e. 


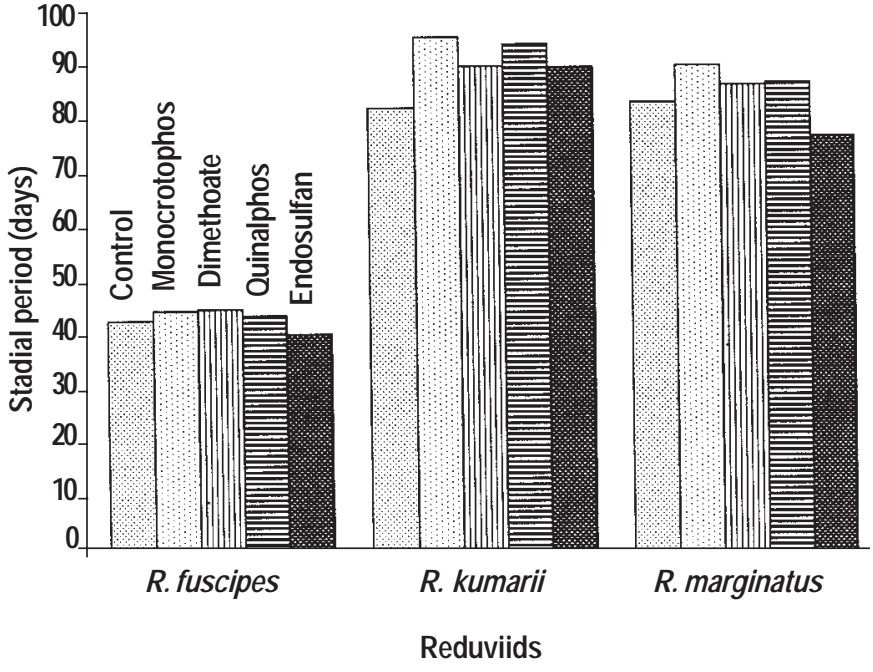

Figure 2. Impact of insecticides on the stadial period (days) of three harpactorine reduviids
(Insecta) and Phytoseiidae (Arachnida). Acetylcholinesterase activities of insecticides and inhibition of hydroxylation processes of some steriods, which subsequently reduce the availability of ecdysone were reported as the mechanisms by which insecticides could reduce the stadial period (Conney et al., 1966; Katiyar \& Lemonde, 1972).

Endosulfan in R. marginatus and dimethoate in R. fuscipes shifted the female-biased sex ratio into male-biased sex ratio. An insecticide applied to a given natural enemy species may affect males and females differentially due to sex-related differences in physiology or phenology or behaviour. Insecticides influenced shifts in sex ratio were reported in insects belonging to Braconidae, Lygaeidae and Scelionidae (Croft, 1990). Such aberration in sex ratios may affect mate finding and other behaviours of an exposed individual. The change of sex ratio was attributed due to the effect of insecticides on the hormonal system (Croft, 1990; George, 1996).

Except endosulfan, all the other insecticides caused significant reduction $(\mathrm{p}=0.5 \%$ to $5 \%)$ in the size and weight of life stages (Tables 3, 4; Figures 3, 4). Similar reduction or increase in weight of natural enemies exposed to insecticides was reported by Croft

Table 3. Impact of insecticides on the morphometry $(\mathrm{mm})$ of three harpactorine reduviids $(n=6 ; \pm S E)$

\begin{tabular}{llllllllll}
\hline Insecticides & Head & \multicolumn{5}{c}{ Prothorax } & \multicolumn{3}{l}{ Abdomen } \\
& RF & RK & RM & RF & RK & RM & RF & RK & RM \\
\hline Control & $2.71 \pm 0.02$ & $4.32 \pm 0.04$ & $3.01 \pm 0.03$ & $1.19 \pm 0.03$ & $1.53 \pm 0.06$ & $1.76 \pm 0.06$ & $6.11 \pm 0.24$ & $7.85 \pm 0.09$ & $7.38 \pm 0.18$ \\
Monocrotophos & $2.67 \pm 0.01$ & $4.16 \pm 0.02$ & $3.88 \pm 0.03$ & $1.11 \pm 0.03$ & $1.44 \pm 0.02$ & $1.62 \pm 0.02$ & $5.42 \pm 0.17$ & $8.12 \pm 0.20$ & $7.02 \pm 0.89$ \\
Dimethoate & $2.09 \pm 0.02$ & $4.25 \pm 0.02$ & $4.04 \pm 0.02$ & $1.15 \pm 0.02$ & $1.48 \pm 0.02$ & $1.81 \pm 0.03$ & $6.18 \pm 0.20$ & $8.06 \pm 0.14$ & $7.27 \pm 0.15$ \\
Quinalphos & $2.74 \pm 0.01$ & $4.32 \pm 0.04$ & $3.94 \pm 0.03$ & $1.18 \pm 0.02$ & $1.52 \pm 0.04$ & $1.75 \pm 0.03$ & $5.76 \pm 0.21$ & $8.15 \pm 0.35$ & $7.03 \pm 0.12$ \\
Endosulfan & $2.99 \pm 0.19$ & $4.42 \pm 0.34$ & $4.52 \pm 0.02$ & $1.16 \pm 0.02$ & $1.59 \pm 0.05$ & $1.85 \pm 0.03$ & $6.42 \pm 0.14$ & $7.91 \pm 0.08$ & $8.13 \pm 0.17$ \\
\hline
\end{tabular}

Source: George, 1996; George \& Ambrose, 1998c, 1999c, 1999e.

RF - Rhynocoris fuscipes, RK - Rhynocoris kumarii, RM - Rhynocoris marginatus

Table 4. Impact of insecticides on the body weight, the fecundity and the longevity of three harpactorine reduviids ( $n=6$; \pm SE)

\begin{tabular}{llllllllll}
\hline Insecticides & & \multicolumn{3}{l}{ Weight $(\mathrm{mg})$} & & \multicolumn{2}{l}{ Fecundity (no.) } & \multicolumn{3}{c}{ Longevity (days) } \\
& RF & RK & RM & RF & RK & RM & RF & RK & RM \\
\hline Control & $47.83 \pm 3.54$ & $167.17 \pm 9.33$ & $143.66 \pm 1.13$ & $86.67 \pm 6.59$ & $108.50 \pm 8.59$ & $175.17 \pm 10.11$ & $34.83 \pm 2.59$ & $108.67 \pm 6.05$ & $125.67 \pm 7.39$ \\
Monocrotophos & $44.17 \pm 3.26$ & $157.00 \pm 7.03$ & $134.17 \pm 8.79$ & $57.33 \pm 3.95$ & $60.50 \pm 5.14$ & $99.50 \pm 3.25$ & $27.83 \pm 1.49$ & $91.50 \pm 4.27$ & $81.17 \pm 7.21$ \\
Dimethoate & $44.67 \pm 3.46$ & $163.83 \pm 9.10$ & $142.83 \pm 11.15$ & $68.00 \pm 2.98$ & $88.33 \pm 5.33$ & $121.17 \pm 6.89$ & $32.50 \pm 2.08$ & $97.67 \pm 7.33$ & $120.50 \pm 4.66$ \\
Quinalphos & $46.17 \pm 3.56$ & $167.67 \pm 8.87$ & $141.17 \pm 9.78$ & $69.00 \pm 5.63$ & $78.17 \pm 4.74$ & $103.00 \pm 5.89$ & $32.50 \pm 1.88$ & $113.00 \pm 7.26$ & $99.50 \pm 7.03$ \\
Endosulfan & $52.83 \pm 3.95$ & $171.67 \pm 9.57$ & $146.17 \pm 10.72$ & $91.00 \pm 4.03$ & $103.00 \pm 6.53$ & $142.50 \pm 8.66$ & $41.83 \pm 2.82$ & $118.67 \pm 4.93$ & $146.83 \pm 13.01$ \\
\hline
\end{tabular}

Source: George, 1996; George \& Ambrose, 1998c, 1999c, 1999e.

RF - Rhynocoris fuscipes, RK - Rhynocoris kumarii, RM - Rhynocoris marginatus 


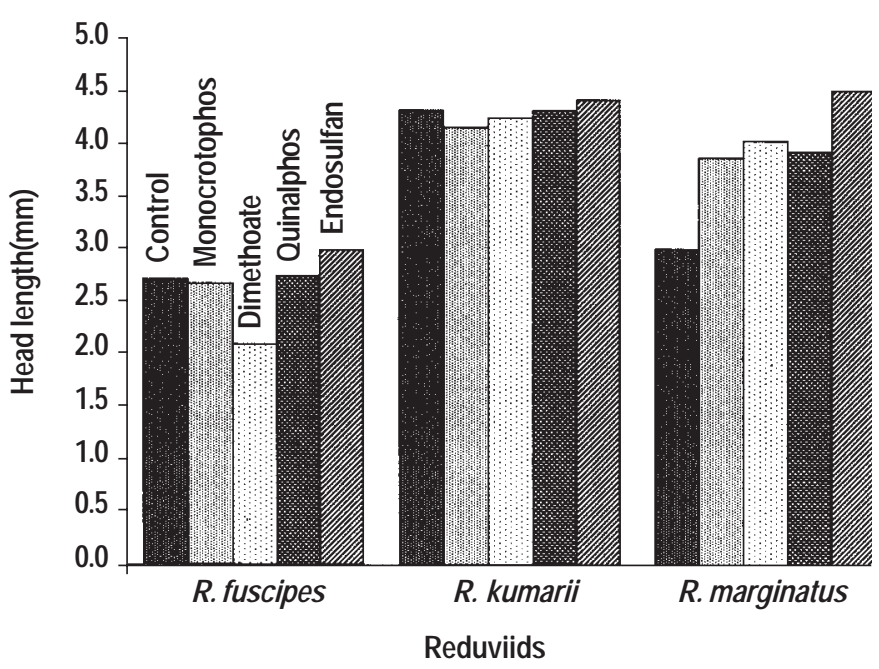

Figure 3. Impact of insecticides on the head length ( $\mathrm{mm})$ of three harpactorine reduviids

(1990). The reduction in size and weight of reduviids due to insecticides was attributed to the blocking of lactate and succinate dehydrogenase and cytochrome oxidase in energy metabolism (Dimov \& Kaloyanova, 1967; Mozsic et al., 1969; Javid \& Ali, 1984; Edmunds \& Alstad, 1985; Khowaja et al., 1994).

Fecundity was reduced by the exposure of insecticides, except endosulfan. There was a negative correlation between the

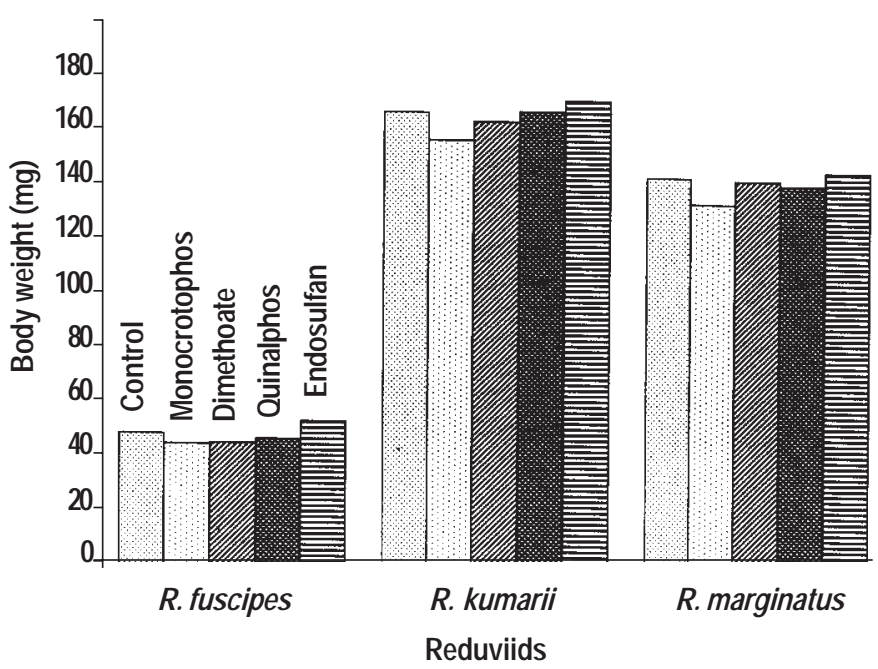

Figure 4. Impact of insecticides on the body weight $(\mathrm{mg})$ of three harpactorine reduviids

concentration of insecticides and the fecundity (Table 4; Figure $5)$. Insecticides caused reduced fecundity in natural enemies belonging to Braconidae, Coccinellidae, Chrysopidae, Scelionidaea, Syrphidae, Trichogrammatidae, Cecidomyiidae, Aphelinidae (Insecta) and Phloseiidae (Arachnida) (Croft, 1990). The reduced fecundity by insecticides was caused by the disruption of parental reproductive physiology or it might be due to the lower food intake (Adkisson \& Wellso, 1962; Picket \& Patterson, 1963; Georghiou, 1965; Ridgway et al.,

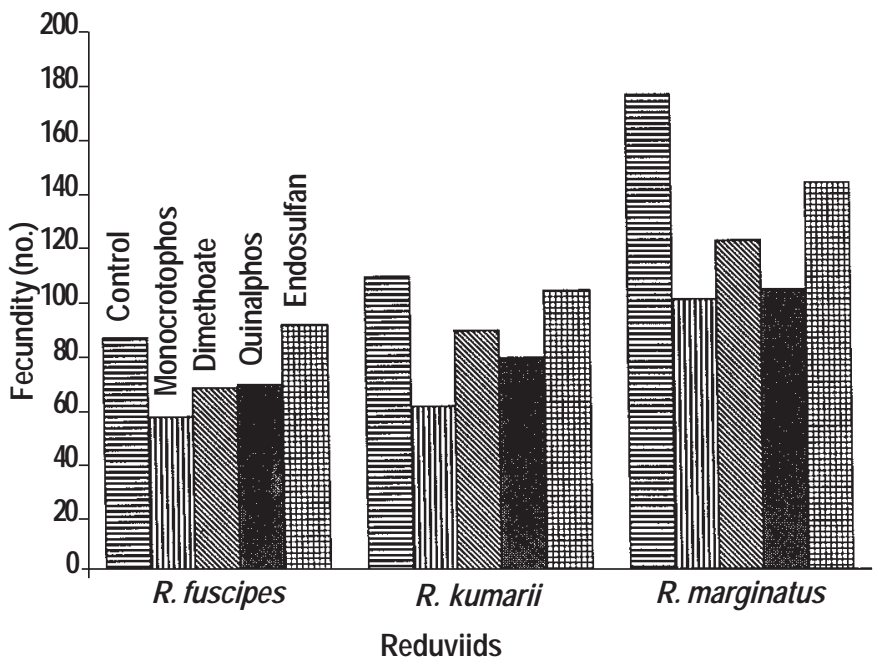

Figure 5. Impact of insecticides on the fecundity of three harpactorine reduviids

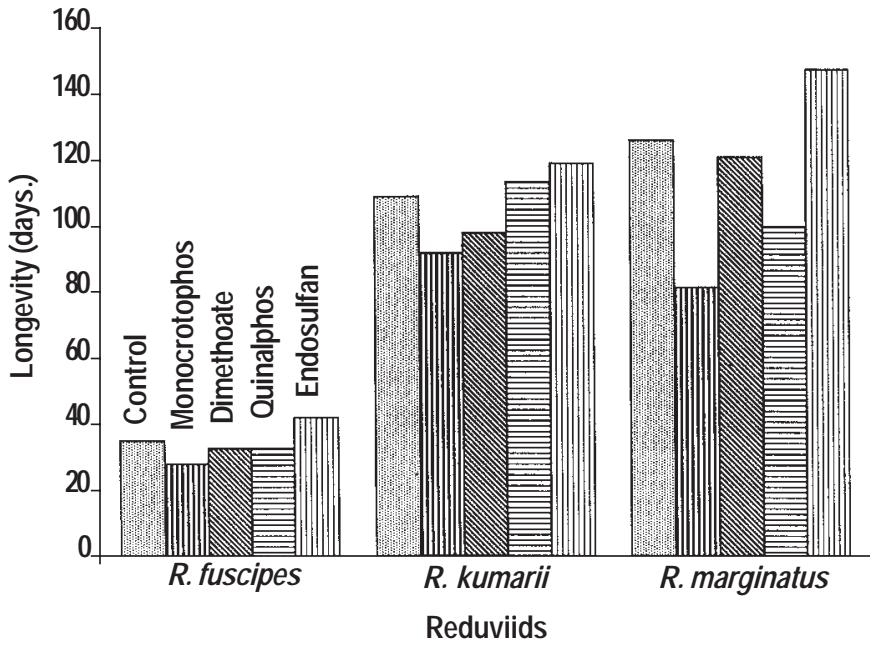

Figure 6. Impact of insecticides on the longevity (days) of three harpactorine reduviids 
1965; Moriarty, 1969; Bariola \& Lindquist, 1970; Schricker \& Stephen, 1970; Barker \& Waller, 1978; Waller \& Barker, 1979; Stoner et al.,1983; Smirle et al., 1984; Harmon \& Ross, 1987, 1988; Haynes, 1988; Hamilton \& Schal, 1990; Senguttuvan \& Gopalan, 1990; Morse \& Zarch 1991; Khowaja et al., 1991, 1992, 1993, 1994). Higher fecundity in endosulfan-treated insects was attributed to the hyperactivity of exposed insects due to the accumulation of acetylcholine. (Georghiou, 1965; Ball \& Su, 1979; Harnoto et al., 1984; Abd-elghafar \& Appel, 1992). Increased synthesis of vitellogenin and increased fecundity due to hydroprene, DDT triforine and triprene were reported in other natural enemies (Croft, 1990). In Bracon hebetor fecundity was reduced by a behavioural effects via nervous system toxication (Croft, 1990).

Insecticides reduced longevity. As the concentration of insecticide was increased, the longevity proportionately reduced (Table 4; Figure 6). Similar Insecticides caused dose dependent reduction or increase in longevity was observed for other natural enemies (Croft, 1990).

In the case of reduced longevity wherein death occurs before the adult stage is reached, the effect on fecundity is obviously zero. In term of life table parameters this effect is equivalent to instantaneous death. However, such affected beneficials may still feed on their hosts or prey during the larval stage and this contributes to a functional response, if not a numerical response. The situation is similar to sterility, where a sterilized beneficial is functionally equivalent to a dead one in terms of intrinsic rate of increase. Sterilized insects may also influence population dynamics by mating with the reproductively viable unaffected beneficials. For instance, in Bracon hebetor, carbamate pesticides interfere with mitotic apparatus and causes poor egg hatch accompanied by only a slight decrease in egg production. It has been suggested that such sterilized females ought to trap the sperms from males, which would have even greater effects on the population's reproductive performance (Croft, 1990).

\section{Behaviour}

Reduction in feeding, haphazard movement, loss of orientation, spitting of saliva and frequent rubbing of rostrum against the prosternal groove, indicating their restlessness were the abnormal behaviours of reduviids exposed to insecticides. The abnormal behaviours were exhibited immediately after their exposure and gradually diminished thereafter. The intensity of abnormal behaviour increased as the concentration of insecticides was increased (George, 1996; Ambrose \& George, 1998; Khan, 2000). Increased or decreased locomotion as a function of insecticidal exposure was reported in natural enemies belonging to Carabidae, Dermaptera, Trichogrammatidae and Formicidae (Insecta) and Phytoseiidae (Arachnida) (Croft, 1990). Moreover, insecticidal exposure served as repellents in the searching behaviour of natural enemies belonging to
Aphelinidae, Syrphidae and Trichogrammatidae. Insecticide exposed natural enemies also exhibited decreased feeding rate or altered food preference (Croft, 1990). In the assassin bug, A.pedestris, cypermethrin affected mating (Khan, 2000). In addition, insecticides caused reduced oviposition, repelled the natural enemies to oviposit or caused deformed ovipositor in insect and arachnid natural enemies. Sublethal doses of insecticides can repel the predator and affect the completion of any one of the predatory behavioural events and disrupt prey location and capturing. Such repellency also disrupts actual oviposition or host acceptance. Insecticides-induced increased mobility can influence the rate of insecticide uptake and therefore insecticide-induced mortality; it can also be beneficial in increasing predation. Relatively long periods of immobility may lead to increased susceptibility of an individual, for example, predation, desiccation and other mortality factors. Such abnormal behaviours resulted, because insecticides could disrupt central nervous system which subsequently affect the neurotropically regulated energy-dependent phenomenon (O'Brien, 1967; Schricker \& Stephen, 1970; Schricker, 1974a, b; Hirata \& Sogawa, 1976; Wantanabe \& Fukame, 1977; Lund et al., 1979; Hoy \& Dahlsten, 1984; Villacarlos, 1987; Linn \& Roelofs, 1984; Elzen et al., 1989).

\section{Predatory potential}

Cypermethrin altered the functional response of the reduviid predator A.pedestris. They prolonged the prey capturing time, and reduced the attack ratio and discovery time (Khan, 2000).

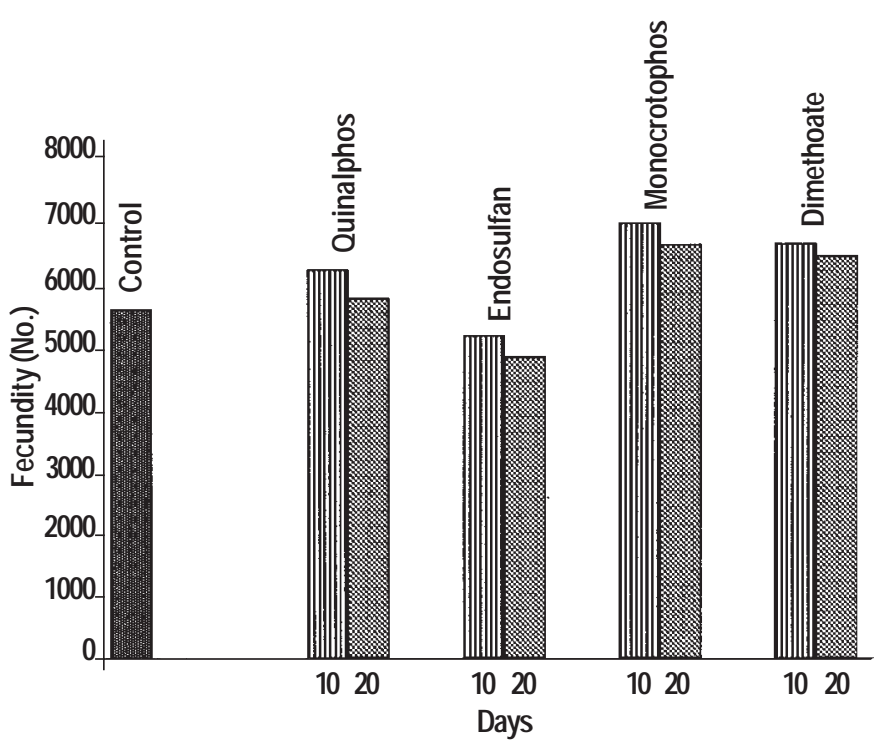

Figure 7. Effect of insecticides on the total count of haemocytes in A. pedestris 
Table 5. Effect of four insecticides on the differential haemocyte count in a reduviine reduviid A. pedestris ( $n=6$; \pm SE)

\begin{tabular}{|c|c|c|c|c|c|c|}
\hline \multirow[t]{2}{*}{ Insecticides } & \multirow[t]{2}{*}{ Duration (days) } & \multicolumn{5}{|c|}{ Haemocytes (\%) } \\
\hline & & Prohaeamocyte & Plasmatocyte & Granular haemocyte & Cystocyte & Oenocytoid \\
\hline Control & - & $14.43 \pm b c 0.73$ & $21.41 \pm b c 0.67$ & $45.06 \pm a 0.6$ & $14.00 \pm a 0.60$ & $5.10 \pm \mathrm{bcd} 0.28$ \\
\hline \multirow[t]{2}{*}{ Quinalphos } & 10 & $11.79 \pm \mathrm{c} 0.65$ & $20.53 \pm c 0.94$ & $49.72 \pm 0.95$ & $11.09 \pm \mathrm{ac} 0.60$ & $6.87 \pm \mathrm{a} 0.49$ \\
\hline & 20 & $15.30 \pm \mathrm{b} 0.74$ & $25.03 \pm a b 0.77$ & $42.61 \pm a b 0.69$ & $10.63 \pm b c 0.55$ & $6.43 \pm a b 0.15$ \\
\hline \multirow[t]{2}{*}{ Endosulfan } & 10 & $16.92 \pm a b 0.58$ & $25.98 \pm 20.85$ & $39.06 \pm b 0.91$ & $11.64 \pm \mathrm{ac} 0.96$ & $6.39 \pm \mathrm{ac} 0.58$ \\
\hline & 20 & $18.90 \pm a 0.45$ & $30.39 \pm 1.13$ & $32.04 \pm 1.41$ & $13.22 \pm a b 0.83$ & $5.45 \pm \mathrm{ad} 0.56$ \\
\hline \multirow[t]{2}{*}{ Monocrotophos } & 10 & $13.00 \pm 0.84$ & $18.84 \pm b d 0.58$ & $50.31 \pm a b c 0.78$ & $11.69 \pm \mathrm{ae} 0.61$ & $9.15 \pm a 0.29$ \\
\hline & 20 & $14.52 \pm 0.21$ & $24.69 \pm a 0.28$ & $42.11 \pm b d g 0.59$ & $12.12 \pm$ acd 0.57 & $6.55 \pm \mathrm{ce} 0.17$ \\
\hline \multirow[t]{2}{*}{ Dimethoate } & 10 & $12.17 \pm 1.07$ & $20.41 \pm b c 0.69$ & $49.91 \pm$ cde 0.98 & 13.12 $\pm a b 0.82$ & $7.39 \pm b c 0.48$ \\
\hline & 20 & $14.41 \pm 0.66$ & $24.55 \pm \mathrm{a} 0.89$ & $43.24 \pm$ egf1.25 & $11.11 \pm a f 0.67$ & $6.68 \pm \mathrm{cd} 0.39$ \\
\hline
\end{tabular}

Source: Ambrose \& George, 1996a, 1996b; George \& Ambrose, 1998d.

Table 6. Effect of four insecticides on the total count of haemocytes in a reduviine reduviid A. pedestris $(n=10 ; \pm S E)$

\begin{tabular}{llll}
\hline Insecticides & $\begin{array}{l}\text { Duration } \\
\text { (days) }\end{array}$ & Range & Total cells $/ \mathrm{mm}^{3}$ \\
\hline Control & - & $42500-71250$ & $53875 \pm 2475.44$ \\
Quinalphos & 10 & $43750-73750$ & $60000 \pm 3421.03$ \\
& 20 & $40000-70000$ & $55625 \pm 3487.63$ \\
Endosulfan & 10 & $41250-63750$ & $49750 \pm 1861.69$ \\
& 20 & $38750-61250$ & $46500 \pm 1934.87$ \\
Monocrotophos & 10 & $48750-77500$ & $67250 \pm 3515.16$ \\
& 20 & $46250-77500$ & $64000 \pm 3311.68$ \\
Dimethoate & 10 & $46250-75000$ & $64125 \pm 3260.15$ \\
& 20 & $45000-72500$ & $62250 \pm 3100.45$ \\
\hline
\end{tabular}

Source: Ambrose \& George, 1996a, 1996b; George \& Ambrose, 1998d.

\section{Haematology}

Insecticides viz., quinalphos, endosulfan, monocrotophos and dimethoate uniformly increased the total and affected the differential haemocyte count in A. pedestris (Ambrose \& George, 1996a, b) (Table 5, 6; Figure 7).

Differential effects of insecticides at varied concentration on the total and differential haemocyte counts of R.kumarii, $R$. marginatus and $R$. fuscipes were observed (George, 1996; George \& Ambrose, 1998d; 2000) (Table 7, 8).

Increased percentage of prohaemocyte as a function of
Table 7. Effect of sublethal concentration (1/10 of $\left.48 \mathrm{hr} L C_{50}\right)$ of four insecticides at 20 days duration on total haemocyte count in three harpactorine reduviids ( $n=10$; $\pm S E$ ).

\begin{tabular}{llll}
\hline Insecticides & \multicolumn{3}{c}{ Total haemocyte count } \\
& RK & RM & RF \\
\hline Control & $8900 \pm 305.532$ & $12220 \pm 422.990$ & $6575 \pm 171.001$ \\
Monocrotophos & $15725 \pm 275.024$ & $16375 \pm 264.204$ & $9225 \pm 205.667$ \\
Dimethoate & $10450 \pm 110.564$ & $14125 \pm 274.519$ & $5775 \pm 120.484$ \\
Quinalphos & $12275 \pm 264.730$ & $12325 \pm 258.356$ & $7275 \pm 184.294$ \\
Endosulfan & $7550 \pm 210.177$ & $8725 \pm 328.007$ & $5425 \pm 182.780$
\end{tabular}

RF - Rhynocoris fuscipes, RK - Rhynocoris kumarii, RM - Rhynocoris marginatus

Source: George, 1996.

insecticidal exposure was attributed to increased mitosis (Jones, 1962; Mall \& Gupta, 1982) and reduction in plasmatocytes was due to the transformation of the plasmatocytes into granular haemocytes for cellular defence by loss of a portion of cytoplasm or by fragmentation or by gradual rounding off of fusciform plasmatocytes (Gupta \& Sutherland, 1966; Beaulaton \& Monpeyssin, 1976; Pathak \& Kulshreshtha, 1993). The increased plasmatocytes by endosulfan was attributed to the normal mitosis of plasmatocytes. Increased granular haemocytes was due to the detoxification of haemocytes (Patton, 1961; Wago, 1980; Kurihara et al., 1992). Reduction in granular haemocytes at certain endosulfan concentrations was due to the 
Table 8. Effect of sublethal concentrations ( $1 / 10$ of $\left.48 \mathrm{hr} L C_{50}\right)$ of four insecticides at 20 days duration on differential haemocyte count in three harpactorine reduviids $(n=10 ; \pm S E)$

\begin{tabular}{|c|c|c|c|c|}
\hline Haemocytes & Insecticide & RK & $\begin{array}{l}\text { Differential count } \\
\text { RM }\end{array}$ & RF \\
\hline Prohaemocyte & $\begin{array}{l}C \\
M C \\
D \\
Q \\
E\end{array}$ & $\begin{array}{l}18.730 \pm 1.669^{a} \\
15.720 \pm 0.435^{a} \\
18.978 \pm 0.128^{a} \\
18.465 \pm 0.537^{a} \\
18.913 \pm 0.660^{a}\end{array}$ & $\begin{array}{l}12.635 \pm 1.226^{\mathrm{a}} \\
10.928 \pm 0.331^{\mathrm{ab}} \\
10.117 \pm 0.365^{\mathrm{ad}} \\
10.143 \pm 0.356^{\mathrm{ac}} \\
8.860 \pm 0.508^{\mathrm{bcd}}\end{array}$ & $\begin{array}{l}21.793 \pm 1.136^{c} \\
23.295 \pm 0.435^{\text {bc }} \\
25.682 \pm 0.492^{a b} \\
26.025 \pm 0.450^{a} \\
27.572 \pm 0.435^{a}\end{array}$ \\
\hline Plasmatocyte & $\begin{array}{l}C \\
M C \\
D \\
Q \\
E\end{array}$ & $\begin{array}{l}42.117 \pm 1.498 \\
38.328 \pm 1.147 \\
39.793 \pm 0.602 \\
42.232 \pm 0.667 \\
49.105 \pm 1.229\end{array}$ & $\begin{array}{l}36.370 \pm 1.799^{b c} \\
40.355 \pm 0.345^{a b} \\
42.075 \pm 0.849^{a} \\
44.748 \pm 0.981^{a} \\
54.738 \pm 1.129\end{array}$ & $\begin{array}{l}47.653 \pm 1.871^{a b} \\
39.775 \pm 0.556 \\
45.857 \pm 0.611^{b} \\
43.917 \pm 0.532^{b} \\
51.097 \pm 0.744^{a}\end{array}$ \\
\hline Granular Haemocyte & $\begin{array}{l}C \\
M C \\
D \\
Q \\
E\end{array}$ & $\begin{array}{l}23.095 \pm 1.535^{\mathrm{b}} \\
29.730 \pm 1.361^{\mathrm{a}} \\
27.903 \pm 0.293^{\mathrm{a}} \\
23.382 \pm 0.735^{\mathrm{b}} \\
18.335 \pm 0.618\end{array}$ & $\begin{array}{l}35.257 \pm 0.721 \\
31.555 \pm 0.538^{a} \\
30.215 \pm 0.856^{a} \\
24.008 \pm 0.449^{a} \\
20.482 \pm 0.587^{a}\end{array}$ & $\begin{array}{l}17.953 \pm 1.372^{\mathrm{a}} \\
24.093 \pm 0.693 \\
14.693 \pm 0.700 \\
19.838 \pm 0.394^{\mathrm{a}} \\
11.450 \pm 0.460\end{array}$ \\
\hline Cystocyte & $\begin{array}{l}C \\
M C \\
D \\
Q \\
E\end{array}$ & $\begin{array}{l}6.932 \pm 0.342^{\mathrm{bw}} \\
9.043 \pm 0.471^{\mathrm{a}} \\
7.523 \pm 0.591^{\mathrm{ab}} \\
6.697 \pm 0.350^{\mathrm{b}} \\
5.665 \pm 0.345^{\mathrm{bc}}\end{array}$ & $\begin{array}{l}5.885 \pm 0.426^{d} \\
7.248 \pm 0.165^{c d} \\
9.932 \pm 0.281^{a} \\
9.338 \pm 0.452^{a b} \\
9.880 \pm 0.309^{a}\end{array}$ & $\begin{array}{l}5.898 \pm 0.746^{a} \\
5.480 \pm 0.356^{a c} \\
5.742 \pm 0.355^{a b} \\
3.697 \pm 0.265^{d} \\
3.878 \pm 0.198^{b c d}\end{array}$ \\
\hline Oenocytoid & $\begin{array}{l}C \\
M C \\
D \\
Q \\
E\end{array}$ & $\begin{array}{l}9.082 \pm 1.249^{\mathrm{a}} \\
7.175 \pm 0.301^{\mathrm{ab}} \\
5.818 \pm 0.358^{\mathrm{b}} \\
9.227 \pm 0.138^{\mathrm{a}} \\
5.507 \pm 0.441^{\mathrm{b}}\end{array}$ & $\begin{array}{l}9.853 \pm 0.750^{b} \\
9.913 \pm 0.135^{b} \\
7.662 \pm 0.337^{c} \\
11.762 \pm 0.320^{a} \\
6.040 \pm 0.298^{c}\end{array}$ & $\begin{array}{l}6.705 \pm 1.026^{\mathrm{ad}} \\
7.358 \pm 0.578^{\mathrm{ac}} \\
8.025 \pm 0.558^{\mathrm{ab}} \\
6.520 \pm 0.458^{\mathrm{ad}} \\
6.005 \pm 0.472^{\mathrm{bcd}}\end{array}$ \\
\hline
\end{tabular}

Means carrying same alphabet in a column are not significantly different at $5 \%(p>0.05)$ by Tukey test.

C - Control; MC - Monocrotophos; D - Dimethoate; Q - Quinalphos; E - Endosulfan.

RF - Rhynocoris fuscipes, RK - Rhynocoris kumarii, RM - Rhynocoris marginatus

Source: George, 1996; George \& Ambrose, 2000.

transformation of granular haemocyte into cystocyte or oenocytoid by extension of some cytoplasmic granules and accumulation of chromatin granules along the inner periphery of the nuclear membrane (Gupta \& Sutherland, 1966). Increase or decrease in cystocytes reflected the coagulation of haemolymph, since cystocytes are considered as the effect of coagulation. The increase in oenocytoids by insecticides further supported their defensive function and their reduction was attributed to their transformation (Kurihara et al., 1992).

Except endosulfan (1/10 conc) all of the other insecticides increased the total haemocyte count in $R$. fuscipes, $R$. kumarii and $R$. marginatus. Methylparathion caused the highest impact (George, 1996). Increased THC reflected the insecticidal resistance. When insecticides reached the central nervous system, diuretic hormone was released which reached 
haemolymph through copora cardiaca and accelerated the rate of excretion. This caused an reduction in the volume of haemolymph which in turn increased the haemocyte count (Lee, 1961; Patton, 1961; Feir, 1979; Pathak, 1983, 1991). Decreased THC in endosulfan exposed reduviids suggests antagonstic action of antidiuretic hormone (Wheeler, 1963; Pathak, 1991). The highest THC observed in R. marginatus was correlated to its relatively higher resistance.

\section{Biochemistry}

Both in the digestive system as well as in the entire insect body, insecticides except quinalphos reduced the total carbohydrate content in $R$. marginatus. Similarly, protein content was also reduced. Insecticides except monocrotophos increased the total lipid content in R. kumarii. They (except endosulfan) caused reduction in the dry matter and increased the water content. The highest impact was caused by methylparathion (George, 1996; George \& Ambrose, 1999b, d). Reduction in carbohydrate was attributed to its utilization at the time of high energy demand warranted due to altered metabolism. Increased oxygen uptake with larger amount of the intermediates of glycolysis and Kreb's TCA cycles was observed in insecticide treated hyperactive insects (Mansingh, 1972; Ahamed et al., 1978; Reddy \& Rao, 1982; Chockalingam et al., 1988; Machale et al., 1991). Utilization of protein at the time of depletion of carbohydrate and derranged protein synthesis, active entry of protein from the gut to heamolymph, proteolysis due to histopathological changes etc. were attributed for the reduction in the protein level (Maheswari \& Sehgal, 1981; Reddy \& Rao, 1982; Bharathi \& Govindappa, 1987a, b; Chockalingam et al., 1988).

Since lipid is impermeable to water, the increased concentration of lipid in the tissues of insecticides treated insects might be related to an adaptation to check the entry of insecticides into the tissues (Wigglesworth, 1972; Chockalingam et al., 1988). Increased water content was due to possible resorption or regurgitation of haemolymph water into the intestine (Mansingh \& Rawlins, 1979; Bharathi \& Govindappa, 1987a). Increased total water content was attributed to lesser loss of water through transpiration and faeces due to the increased fat content of the body and the lesser water utilization in insecticide treated insects (Delvi \& Pandian, 1971; Srinivasan, 1977; Pandian et al., 1978; Ross \& Brown, 1982; Delvi, 1983; Naik \& Delvi, 1984).

\section{Histology}

Insecticides extensively damaged the histology of three reduviids (George, 1996). Insecticides caused lysis of intercellular connecting material resulting into gaps between epithelial cells causing frilled appearance, cellular degeneration, destruction of intestinal mucosa, pycnotic nucleus, vacuolization, obliteration of peritrophic membrane, appearance of fat globules, evagination of inner cellular tips and subsequent projection into the lumen, vacuolization caused exfoliation of cells and interluminal migration of broken cells, degeneration of nucleus, condensation of chromatin and darkly and evenly stained perinuclear cytoplasm in the alimentary canal. Twentyday exposure caused necrosis of intestinal epithelial cells. Vacuolization and apparent secretion in gut cells suggest metabolic disturbance due to hyperactivity caused by neuromuscular poisoning of insecticides. The proliferation of entire cell might mainly be due to the osmotic pressure changes created by the insecticides inside the epithelium (Topozada $e t$ al., 1968; Lal et al., 1970; Rizvi, 1970).

Insecticides caused reduction in sperm amount, distortion of sperm cells and connective tissues, vacuolated spermatocytes and spermatids with pycnotic nucleus, reduction in interfollicular septum and testicular cysts, inhibition of spermatogenesis, spermatid cysts necrosis and thin and short spermatozoa. Prolonged exposure (20 days) caused disintegration of testis, fragmentation of spermatocytes, loss of sperm motility and degeneration and resorption of spermatozoa. Histomorphological dearrangement in the growth and differentiation was due to the physiological imbalance or stress or hyperactivity caused by insecticide's inhibitory action (Nath et al., 1978; Misra, 1981; Ahi, 1988; Maheswari et al., 1981; Bhalerao et al., 1991; Paul et al., 1991; Reinecke et al., 1969).

Crumbling of follicular epithelium, disintegration of trophocytes, vacuolization of germarium, degeneration of yolk platelets, uneven pycnotic follicular layer, vacuolated ooplasm and dislocation of basement membrane were observed in insecticide treated reduviids. Complete necrosis was seen in 20-day monocrotophos and methylparathion exposed reduviids. The aberration observed in the ovary was attributed to the failure of supply of trophic material like ribonucleoprotein and DNA to the vitellarium. Poor deposition of yolk was attributed to degeneration of follicular epithelium. Multinucleated oocytes were resulted due to amitotic division of oocyte nucleus. Reabsorption of mature ova and oocytes and drastic decrease in fat cell size were observed as in starved individuals. This might be due to altered physiology of the state of "knock-down" i.e., increased rate of heart beat, increased chemical activity in the ganglia and fat body participation in carbamate metabolism. Moreover, damage of intracellular mitotic apparatus, resulting in embryo mortality during cleavage and subsequent reduction in egg hatch (Landa \& Rezabora, 1965; Ondracek \& Matolin, 1971; Nath et al., 1976).

\section{Conclusion}

The foregoing account about the impact of commonly used insecticides on the non-target beneficials reveals that chemical control of insect pests can produce the following sublethal effects: (i) direct effects of toxicants on the nervous system; (ii) indirect effects caused by chemical upset of the hormonal system and consequent changes in the titres of endocrine secretion; 
and (iii) direct effects on non-neural target sites, such as those involved in protein synthesis. Exposure to insecticide can and probably often does result in all three types of effects simultaneously, with the outcome depending on the specific compound dose and physiological state of the affected organism. Cases of latent toxicity may be caused by the interaction of insecticides with normal physiological processes. It is time to replace the "king chemical" and especially those that are not friendly with beneficials.

Hence, the author suggests the screening of insecticides in such a way that they should manage or control the insect pest population but should be safer to the non-target beneficials. Although botanicals are comparatively safer than synthetic insecticides to beneficials, screening of available botanicals enable us to choose insecticides which are least toxic to beneficials but effective against target pests. Hence, beneficialsfriendly insecticides or 'soft' insecticides must be identified, promoted and incorporated in the Integrated Pest Management Programmes. Such biorational insecticides, including insect growth regulators, chitin synthesis inhibitors, anti-feedants, etc. usually cause lower natural enemy mortality than conventional synthetic insecticides. Physiological selectivity offer pesticide selectivity. Such pesticide selectivity has to be achieved in relation to the tritrophic biochemical interactions between plant pests and natural enemies by incorporating natural toxicants, antifeedants, suppressants, juvenoids or antijuvenoids into crop plant tissue by genetic engineering. Such incorporation could affectively reduce pest population development, while not affecting their natural enemies.

\section{Acknowledgements}

The author is grateful to Dr. G. Packiaraj, S.J. Principal and Dr. D. Selvanayakam, S.J. Secretary, St. Xavier's College for facilities; to University Grants Commission, New Delhi, India for financial assistance (F.3 - 27/97 (SR-II)).

\section{References}

Abd-Elghafar, S.F. and A.G. Appel (1992). Sublethal effects of insecticides on adult longevity and fecundity of German cockroaches (Dictyoptera: Blattellidae). Journal of Economic Entomology 85(5): 1809-1817.

Adkission, P.L. and S.G. Wellso (1962). Effect of DDT poisoning on the longevity and fecundity of the Pink Ballworm. Journal of Economic Entomology 55: 842-845.

Ahamed, I.K., M.R. Begum, S. Sivaiah and K.V.R. Rao (1978). Effect of malathion on free aminoacids, total proteins, glycogen and some enzymes of palecypod Lamellidens marginallis Lamarck. Proceedings of the Indian Academy of Science (Animal Science) 87(12): 377-380.

Ahi, J. (1988). Histopathological effects of hexachloro-cyclohexane $(\mathrm{HCH})$ on the testes of adult Poecilocerus pictus (Fabr.) (Orthoptera: Acrididae). Entomon 13(1): 37-41.

Ambrose, D.P. (1999). Assassin Bugs. Science Publishers, New
Hampshire, USA. 337 pp.

Ambrose, D.P. and P.J.E. George (1995). Relative toxicity of three insecticides to Acanthaspis pedestris Stål potential predator of insect pests (Insecta: Heteroptera: Reduviidae). Journal of Advanced Zoology 16(2): 88-91.

Ambrose, D.P. and P.J.E. George (1996a). Effect of monocrotophos, dimethoate and methylparathion on the differential and the total haemocyte counts of Acanthaspis pedestris Stål (Insecta: Heteroptera: Reduviidae). Fresenius Environmental Bullettin 5: 190-195.

Ambrose, D.P. and P.J.E. George (1996b). Effect of quinalphos and endosulfan on the differential and the total haemocyte counts of Acanthaspis pedestris Stål (Insecta: Heteroptera: Reduviidae). Fresenius Environmental Bullettin 5: 207-212.

Ambrose, D.P. and P.J.E. George (1998). Comparative toxicological effects of monocrotophos to the third nymphal instars and the adults of Acanthaspis pedestris Stål, a potential biocontrol agent (Insecta: Heteroptera: Reduviidae). Indian Journal of Environmental Science 2(2): 105-111.

Ball, H.J. and P.P. Su (1979). Effects of sublethal dosages of carbofuran and carbaryl on fecundity and longevity of the western corn root worm. Journal of Economic Entomology 72: 873-976.

Bariola, L.A. and D.A. Lindquist (1970). Longevity and fecundity of boll weevils exposed to sublethal doses of systematic insecticides. Journal of Economic Entomology 72: 873-876.

Barker, R.J. and G.D. Waller (1978). Sublethal effects of parathion, methyparathion or formulated methoprene fed to colonies of honey bees. Environmental Entomology 7: 569-571.

Beaulaton, J. and M. Monpeyssin (1976). Ultrastructure and cytochemistry of the haemocytes of Antheraca pernyi Gyen. (Lepidoptera: Attacidae) during the $5^{\text {th }}$ larval stage I. Prohaemocytes, plasmatocytes and granulocytes. Journal of Ultrastructure Research 55(2): 143-156.

Bhalerao, S., K. Rawat and S. Bhargava (1991). Testicular degeneration in Dysdercus koenigii after microwave exposure. Entomon 16(4): 257-260.

Bharathi, D. and S. Govindappa (1987a). Effect of carbaryl on the organic constituents in gut region of the blister beetle Mylabris pustulata. Environment and Ecology 5(1): 56-59.

Bharathi, D. and S. Govindappa (1987b). Effect of carbaryl on the organic constituents of hemolymph of the blister beetle Mylabris pustulata. Environment and Ecology 5(1): 65-70.

Chockalingam, S., K.P.S. Jeyachandran and B. Shanthy (1988). Effect of sublethal concentrations of dairy effluent on the biochemical constituents in the nymphs of dragon fly Brachythermis contaminata. Pollution Research 7(1-2): 23-28.

Conney, A.H., R.H. Welch, R. Kundtyman and J.J. Burms (1966). Effect of pesticides on drug and steroid metabolism. Clinical Pharmacology and Therapeutics. 8: 2-10.

Croft, B.A. (1990). Arthropod Biological Control Agents and Pesticides. John Wiley \& Sons. New York.

Delvi, M.R. (1983). Dietary water balance in tropical insect. Proceedings of the Indian Academy of Sciences (Animal Science) 92: 135-145.

Delvi, M.R. and T.J. Pandian (1971). Ecophysiological studies on the utilization of food in paddy field grasshopper Oxya velox. Oecologia (Berlin) 8: 267-275.

Dimov, G. and F. Kalayanova (1967). Carbohydrate metabolism disorders in the liver and muscles in acute parathion poisonings. Research Academy of Bulgarian Science 20: 1007-1009. 
Edmunds, G.F., Jr. and D.N. Alstad (1985). Malathion induced sex ratio changes in Black Pineleaf Scale (Hemiptera: Diaspididae). Annals of Entomological Society of America 78: 403-405.

Elzen, G.W., P.J. O' Brien and J.E. Powell (1989). Toxic and behavioural effects of selected insecticides on the Heliothis parasitoid Microplitis croceipes. Entomophaga 34(1): 87-94.

Feir, D. (1979). Multiplication of haemocytes. In: Gupta, A.P. Editor. Insect Haemocytes. Cambridge University Press, Cambridge.

Ghelani, Y.H., H.N. Vyas and R.C. Jhala (2000). Toxicological impact of certain insecticides to Rhinocoris fuscipes Fabricius. Journal of Applied Zoological Research, 11(1): 54-57.

George, P.J.E. (1996). Impact of chosen insecticides on three nontarget reduviid biocontrol agents (Insecta: Heteroptera: Reduviidae). $\mathrm{Ph} . \mathrm{D}$ thesis. Manonmaniam Sundaranar University, Tirunelveli, India (Unpublished).

George, P.J.E. and D.P. Ambrose (1996). Adaptive polymorphism in Rhynocoris marginatus Fabricius to two insecticides, a non-target biocontrol agent (Insecta: Heteroptera: Reduviidae), pp. 121-125. In: Ambrose, D.P., Editor. Biological and Cultural Control of Insect Pests, An Indian Scenario. Tirunelveli, India: Adeline Publishers.

George, P.J.E. and D.P. Ambrose (1997). Relative toxicity of five insecticides to the predator Rhynocoris kumarii Ambrose and Livingstone (Insecta: Heteroptera: Reduviidae). Indian Journal of Environment and Toxicology 8(1): 35-36.

George, P.J.E. and D.P. Ambrose (1998a). Relative toxicity of five insecticides to Rhynocoris marginatus (Fabricius) a potential predator of insect pests (Insecta: Heteroptera: Reduviidae). Fresenius Environmental Bulletin 7: 7-8.

George, P.J.E. and D.P. Ambrose (1998b). Relative toxicity of five insecticides to Rhynocoris fuscipes (Fabricius) a potential predator of insect pests (Insecta: Heteroptera: Reduviidae). Shashpa 5(2): 197202.

George, P.J.E. and D.P. Ambrose (1998c). Effect of insecticides on the post-embryonic development in Rhynocoris marginatus (Fabricius) (Heteroptera: Reduviidae). Journal of Biological Control 12(2): 113118.

George, P.J.E. and D.P. Ambrose (1998d). Total and differential count of haemocytes in the life stages and adult haemocyte morphology in Acanthaspis pedestris Stål. Indian Journal of Entomology 60(3): 228-232.

George, P.J.E. and D.P. Ambrose (1999a). Impact of insecticides on the biochemical constituents in a non-target Harpactorine reduviid, Rhynocoris fuscipes (Fabricius) (Heteroptera: Reduviidae). Shashpa. 6(2): 167-172.

George, P.J.E. and D.P. Ambrose (1999b). Biochemical modulations by insecticides in a non-target harpactorine reduviid Rhynocoris kumarii Ambrose and Livingstone (Heteroptera: Reduviidae). Entomon 24(1): 61-66.

George, P.J.E. and D.P. Ambrose (1999c). Insecticidal impact on the post-embryonic development of Rhynocoris kumarii Ambrose and Livingstone (Heteroptera: Reduviidae). Journal of Applied Entomology 123: 509-512.

George, P.J.E. and D.P. Ambrose (1999d). Biochemical changes by insecticides in a non-target Harpactorine Reduviid Rhynocoris marginatus (Fabricius). Indian Journal of Environment and Toxicology 9(2): 78-80.

George, P.J.E. and D.P. Ambrose (1999e). Post-embryonic developmental changes in non-target Rhynocoris fuscipes (Fabricius) (Insecta: Heteroptera: Reduviidae) by insecticides in cotton agro ecosystem. Journal of Advanced Zoology 20(1): 12-16.

George, P.J.E. and D.P. Ambrose (2000). Impact of five insecticide on the differential and the total haemocyte counts of Rhynocoris marginatus (Fabricius) (Insecta: Heteroptera: Reduviidae). Indian Journal of Environmental Sciences 4(2): 169-173.

Georghiou, G.P. (1965). Effects of carbamates on housefly fecundity, longevity and food intake. Journal of Economic Entomology 58: 5862.

Gupta, A.P. and D.J. Sutherland (1966). In vitro transformations of the insect plasmatocyte in some insects. Journal of Insect Physiology 12: 1369-1375.

Hamilton, R.L. and C. Schal (1990). Sublethal effects of chlorpyrifos methyl on reproduction in female German cockroaches (Dictyoptera: Blattellidae). Journal of Economic Entomology 83: 441443.

Harmon, J.D. and M.H. Ross (1987). Effects of propoxur exposure on female of the German cockroach Blattella germanica and their oothecae. Entomologica Experimentalia et Applicata 44: 269-275.

Harmon, J.D. and M.H. Ross (1988). Effects of malathion and diazinon exposure on female German cockroaches (Dictyoptera: Blattellidae) and their oothecae. Proceedings of Entomological Zoology 90: 248-255.

Harnoto, O., R. Hamada and K. Kiritani (1984). Effect of sublethal dosages of carbaryl on the fecundity of Spodoptera littoralis Fabricius (Lepidoptera: Noctuidae). Applied Entomology and Zoolology 19: 404405.

Haynes, K.F. (1988). Sublethal effects of neurotoxic insecticides on insect behaviour. Annual Review of Entomology 33: 149-168.

Hirata, M. and K. Sogawa (1976). Antifeeding activity of chlordimeform for plant sucking insects. Applied Entomology and Zoology 11: 94-99.

Hoy, J.B. and D.L. Dahlsten (1984). Effects of malathion and Staley's bait on the behaviour and survival of parasitic hymenoptera. Environmental Entomology 13: 1483-1486.

Javid, A.M. and J.N. Ali (1984). Effects of methomyl on weight and development of fall armywork (Lepidoptera: Noctuidae). Annals of Entomological Society of America 77: 193-196.

Jones, J.C. (1962). Current concepts concerning insect haemocytes. American Zoologist 2: 209-246.

Katiyar, V.N. and A. Lemonde (1972). Biological effects of some organophosphate and carbamate insecticides on the confused flour beetle. Journal of Economic Entomology 65: 939-942.

Khan, M.M.M. (2000). Impact of cypermethrin and neemgold on a non-target potential biocontrol agent Acanthaspis pedestris (Stål) (Insecta: Heteroptera: Reduviidae). M.Sc. Thesis. St. Xavier's College, Palayankottai, India (Unpublished).

Khowaja, J., A.K. Mumtaz and A. Qamar (1991). The effect of cythion (malathion) on fecundity, fertility and longevity of red cotton bug D. cingulatus. Proceedings of the $78^{\text {th }}$ Indian Science Congress, Part III, Section IX: 113-114.

Khowaja, J., A.K. Mumtaz, A. Qamar and A.K. Bachchan (1992). Changes in fecundity, fertility longevity and weight of Dysdercus cingulatus (Hemiptera: Pyrrhocoridae) following tropical application of monocrotophos. Proceedings of the $79^{\text {th }}$ Indian Science Congress, Part III, Section IX: 76-77.

Khowaja, J., M.A. Khan, A. Qamar and B.A. Khan (1993). Cytion (an organophosphate) as inhibitor of growth and reproduction of Spodoptera litura Fabr. (Lepidoptera: Noctuidae), a polyphagous insect pest of agricultural crops. Proceedings of the $80^{\text {th }}$ Indian Science 
Congress, Part IV: 187

Khowaja, J., M.A. Khan, A. Qamar and B.A. Khan (1994). Biological effects of sublethal concentrations of monocrotophos on Dysdercus cingulatus Fabr. (Hemiptera: Pyrrhocoridae). Journal of Entomological Research 18(1): 37-44.

Kurihara, Y., T. Shimazu and S. Wago (1992). Classification of haemocytes in the common cutworm Spodoptera litura (Lepidoptera: Noctuidae) I. Phase Microscopic study. Applied Entomology and Zoolology 27(2): 225-235.

Lal, L., D.S. Mishra and S.P. Mukherji (1970). Histopathological studies of certain organophosperous insecticides on the alimentary canal of the tobacco caterpillar Spodoptera litura Fab. Indian Journal of Entomology 32(4): 295-297.

Landa, V. and B. Rezabora (1965). The effect of chemosterilants on the development of reproductive organs of insects. Proceedings of the XII InternationalCongress on Entomology, London 8: 516.

Lee, R.M. (1961). The variation of blood volume with age in the desert locust (Schistocerca gregaria Forsk). Journal of Insect Physiology 6: 36-51.

Linn, C.E. and W.L. Roelofs (1984). Sublethal effects of neuroactive compounds on pheramone response thresholds on male oriental fruit moths. Archives of Insect Biochemistry and Physiology 1: 331-344.

Lund, A.E., R.M. Hollingworth and D.L. Shankland (1979). Chlordimeform: plant protection by sublethal non-cholinergic action on the central nervous system. Pesticide Biochemistry and Physiology 11: 117-128.

Machale, P.R., A.K. Khan and R. Sarojini (1991). Biochemical changes induced by cuprous oxide in the various tissues of the freshwater crab, Barytelphusa guerinii. Journal of Advanced Zoology 12(2): 115-120.

Maheswari, S.C. and S.S. Sehgal (1981). Effect of Tepa on nucleic acid and protein contents in the developing red cotton bug Dysdercus koenigii Fabr. Indian Journal of Entomology 43(4): 341-347.

Maheswari, S.C., S.S. Sehgal and V.K. Sexena (1981). Effect of Tepa on nucleic acid and protein contents in developing red cotton bug Dysdercus koenigii Fabr.. Indian Journal of Entomology 43(4): 341-347.

Mall, S.B. and G.S. Gupta (1982). Haemocyte picture during metamorphosis of Atteva fabriciella (Swed). Indian Journal of Entomology 44(2): 101-112.

Mansingh, A. (1972). Effects of farnesyl methyl ether on carbohydrate and lipid metabolism in the tent caterpillar Malacosoma pluviale. Journal of Insect Physiology 18: 2251-2264.

Mansingh, A. and S.C. Rawlins (1979). Inhibition of oviposition in the cattle tick Boophilus microplus by certain acaricides. Pesticide Science 10: 285-294.

Misra, D.S. (1981). Histopathology of insect tissues exposed to pesticides. Indian Journal Entomology 43: 348-360.

Moriarty, F., (1969). The sublethal effects of synthetic insecticides on insects. Biological Review 44: 321-357.

Morse, J.G. and N. Zarch (1991). Pesticide induced hormologigosis of citrus thrips (Thysanoptera: Thripidae) fecundity. Journal of Economic Entomology 84(4): 1169-1174.

Mozsic, G., B. Kiss, T. Javor, M. Krausz and E. Toth (1969). Effects of cholinesterase inhibitor treatment on the phosperous and nucleic acid metabolism in the stomach wall. Pharmacology (Basel) 2: 45-59.

Naik, P.R. and M.R. Delvi (1984). Effects of insecticide permethrin on dietary water utilization in eri silkworm Philosamia ricini.
Proceedings of the Indian Academy of Science (Animal Science) 93(6): 497-504.

Nath, V., P.K. Mittal and C. Sheikher (1976). Effects of hempa on the gonads of Locusta migratoria (L). Bullettin of Entomological Research 66: 313-315.

Nath, V., P.K. Mittal and C. Sheikher (1978). Effects of Apholate on the gonads of Locusta migratoria. Indian Journal of Entomology 40(1): 74-80.

O'Brien, R.D. (1967). In: Insecticides Action and Metabolism. Academic Press Incorporated, New York, pp 55.

Ondracek, J. and S. Matolin (1971). Sterilizing effects of tepa on the bean beetles Acanthocelides obtects Say (Coleoptera). Acta. Entomologica Bohemoslov 68: 209-215.

Pandian, T.J., R. Pitchairaj, S. Mathavan and S. Palanichamy (1978). Effects of temperature and leaf ration on the water budget of the final instar larva of Danaus chrysippus L. Lepidoptera: Danidae). Monitore Zoologico Italiano 12: 17-28.

Pathak, J.P.N. (1983). Effects of endocrine gland on the unfixed total haemocyte counts of the bug Halys dentata. Jounal of Insect Physiology 29: 91-94.

Pathak, J.P.N. (1991). Effect of endocrine extracts on the blood volume and population of haemocytes in Halys dentata (Pentatomidae: Heteroptera). Entomon 16(4): 251-255.

Pathak, S.C. and V. Kulshreshtha (1993). Variation in haemocyte types with reference to reproductive activity in Blattella germanica L. (Dictyoptera: Blattellidae) and the occurance of undescribed haemocyte types in some adult stages. Entomon 18(3 \&4): 119-125. Patton, R.L. (1961). The detoxication function of insect haemocytes. Annals of the Entomological Society of America 52: 240-242.

Paul, A.V.N. and K.P. Srivastava (1989). Relative toxicity of different insecticides to Chelomus blackburni Cameron on egg-larval parasitoid of cotton bollworms. Pestology XIII(12): 10-12.

Paul, S.K., M.R. Ghosh and C. Sahu (1991). Toxic effects of insecticides in the histomorphology of testes of Diacrisia obliqua Walker (Arctiidae: Lepidoptera). Journal of Economic Entomology 9(1): 55-60.

Picket, A.D., and N.A. Patterson (1963). Arsenates: Effect on fecundity in some Diptera. Science 140(3566): 493-494.

Reddy, G.S. and A.P. Rao (1982). Biochemical studies on the haemolymph and heart muscle of normal and insecticide treated cockroach Periplaneta americana. Proceedings of the Indian Natural Science Academy 46(B): 164-167.

Reinecke, L.R., W. Klassen and J.F. Norland (1969). Damage to the testes and recovery of fertility in boll weevils fed chemo sterlilants. Annals of the Entomological Society of America 62: 511-525.

Ridgway, R.L., S.L. Jones and D.A. Lindquist (1965). Effects of American cyanimid CL47031 on fecundity and longevity of the boll weevil. Journal of Economic Entomology 58: 790-791.

Rizvi, S.A. (1970). The effect of some insecticides on the histopathology of midgut of different stages of Hieroglyphus nigrorepletus Bol. Ph.D. Dissertation, Aligarh Muslim University, Aligarh (Unpublished).

Ross, D.C. and T.M. Brown (1982). Inhibition of larval growth in Spodoptera frugiperda by sublethal dietary concentrations of insecticides. Journal of Agricultural Food and Chem. 30: 193-196.

Sahayaraj, K. (1991). Bioecology, Ecophysiology and Ethology of chosen predatory hemipterans and the potential in Biological control (Insecta: Heteroptera: Reduviidae). Ph.D. Dissertation, Madurai Kamaraj University, Madurai, India (Unpublished). 
Schricker, B. (1974a). Der Einflusa subleteler Dosen von Parathion (E 605) aufdie Entferungsweisung bei der Henigbiene; Apidologie. 5: 149-175.

Schricker, B. (1974b). Der Einflusa subleteler Dosen von Parathion (E 605) aufdas Zeitgedachtnis der Henigbiene. Apidologie. 5: 385398.

Schricker, B. and W.P. Stephen (1970). The effect of sublethal doses of parathion on honeybee behaviour I. Oral administration and the communication dance. Journal of Apiculture and Research 9: 141153.

Senguttuvan, T. and M. Gopalan (1990). Ovicidal activity of insecticides on eggs of brown planthopper Nilaparvata lugens (Stål) in resistant and susceptible rice varieties. Entomon 15(34): 263-265. Smirle, M.J., M.L. Winston and K.I. Woodward (1984). Development of a sensitive bioassay for evaluating sublethal pesticide effects on the honey bee (Hymenoptera: Aididae). Journal of Economic Entomology 77: 63-67.

Srinivasan, R. (1977). Studies on toxicity of methyl xanthines on chosen organisms. Ph.D. Dissertation, Jawaharlal Nehru University, New Delhi (unpublished).

Stoner, A., W.T. Wilson and J. Harvery (1983). Dimethoate, Cygon effect on long term feeding of low doses on honey bees in standard size field colonies. Southwest Entomologist 8: 174-177.
Topozada, A., A.E. Salam, M.W. Eldefraw and M. Weid (1968). Histopathological effects of insecticides on the midgut of the Egyptin cotton leaf worm Spodoptera littoralis Boisd. Annals of the Entomological Society of America 61(5): 1333-1339.

Villacarlos, L.T. (1987). Effect of systemic insecticides on the feeding behaviour and mortality of green peach aphid and its transmission of potato leaf roll virus. Philippines Entomologist 7(2): 121-128.

Wago, H. (1980). Observation of the early process of phagocytosis by the granular cells of the silkworm Bombyx mori. Applied Entomological Zoology 15: 489-491.

Waller, G.D. and R.J. Barker (1979). Effect of dimethate on honey bee colonies. Journal of Economic Entomology 72: 549-551.

Wantanabe, H. and J. Fukame (1977). Stimulating action of chlordimeform and desmethylchlordimeform on motor discharges of armyworm, Lencama separata Walker (Lepidoptera: Noctuidae). Journal of Insect Physiology 28(6): 527-534.

Wheeler, R.E. (1963). Studies on the total haemocyte count and haemolymph volume in Periplaneta americana (L.) with special reference to the last moulting cycle. Journal of Insect Physiology 9: 223-235.

Wigglesworth, V.B. (1972). Haemocytes and basement memberane formation in Rhodnius prolixus. Journal of Insect Physiology 19: 831844. 